\title{
Humanity in Schillebeeckx's hermeneutic phenomenology. Towards a methodology
}

\author{
Ramona Simuț (PhD) \\ Faculty of Theology \\ University of Pretoria, South Africa \\ r.simut@gmail.com
}

\begin{abstract}
This paper offers an analysis of Edward Schillebeeckx's insights on different perceptions of revelation as related to concepts like salvation, God, church, human experience, and creation in the work Jesus in Our Western Culture. The incentive of Schillebeeckx's hermeneutical method in nowadays Western phenomenology, upon which God "breathed his breath of life", triggered our interest in meanings which Schillebeeckx ascribes to human history as the realm of God's work for the benefit of men and women. This meaning is suggested in the very beginning of the book by its original Dutch title If Politics is not Everything. As stated in this work's introduction, Schillebeeckx's main theme is the origin of salvation in the humanum, from the Abba experience to nowadays revelatory events. Our attempt is to see how Schillebeeckx's humanum, which is the embodiment of human experience of consciousness, becomes relevant for the Christian doctrines and why Schillebeeckx reckons that bringing them together would impact both his worldview and Western culture.
\end{abstract}

Key words: Schillebeeckx, Western culture, humanum, hermeneutics, phenomenology

\section{Introduction}

All discussions about social and Christian ethics in Schillebeeckx's thought have to be taken for what they are, namely the support on which he later developed his definition of God, Christology, soteriology and church. The fact that Schillebeeckx, the Flemish theologian based in the Netherlands witnessed the Second World War, the Cold War period, post-totalitarian democracies, and also post-modern society and politics until end of 2009, when he died, was for him an incentive to relate all these experiences to biblical statements in a personal hermeneutics. Our analysis of Schillebeeckx's take on the doctrine of God as reflected in both the Old and the New Testament is the first step toward building the image of the Old 
Testament God conceived in relationship with creation and stories about it. This is because without this interpretative framework of creation, the doctrine about revelation would miss its point, as Schillebeeckx asserts that the New Testament statements about God the creator need be compared with the statements about Jesus the Saviour. Thus, Schillebeeckx brings divine disclosure in human history closer to its full purpose of depicting revelation within godhood and within history.

It is Schillebeeckx's conviction that a genuine doctrine of God, Christ, and man would provide a better understanding of what humanity means in a society of suffering. Consequently, he envisages a study of the ministry of Jesus and the Easter events which conveys the idea of the perfect human action towards human welfare. Schillebeeckx's view on the foundation of human experience and ethics as a relationship between suffering and love is constructed on the model of nowadays church life and its impact on non-believers. This study will bring into discussion the different influences that shaped Schillebeeckx's thought in the course of this work in order to grasp his theory of the humanum as the genuine fulfillment of ethics. Thus, Schillebeeckx's phenomenology will be viewed as a step forward from his insistence on Christian dogma and faith to the new reality of contemporary men and women in their particular settings.

\section{Phenomena and the divine disclosure}

Edward Schillebeeckx's contact with Western phenomenology and anthropology dates back to times previous and during the Second World War, when in 1934 he studied phenomenology in Leuven with the Dominican philosopher Dominic Maria De Petter, who initiated him into neoThomism, the phenomenologies of Husserl and Heidegger ${ }^{1}$, and also opened his mind to the new possibilities of studying Catholic dogma in the light of the historical critical method. ${ }^{2}$ Because traditional Catholicism pertaining to Mediaeval scholasticism viewed as extremely controversial the way in which humanism approached, first, the doctrine of revelation (which was believed to have ended with the last of the apostles), the supreme authority of the Church in proclaiming the inextricable truth of Catholic dogma, and also the path to analysing biblical texts, DePetter's influence on Schillebeeckx's could also be defined as controversial.

$1 \quad$ For details, see Kee-Fook Chia, Edward Schillebeeckx and Interreligious Dialogue, 58.

2 Abdul-Masih, Edward Schillebeeckx and Hans Frei, 55. 
To clarify, Schillebeeckx came to acknowledge that human experience can play an important role in explaining divine revelation and the doctrines of salvation, sin, and redemption. This shift was especially favored by the fact that right after the War, Schillebeeckx began travelling for studies in France, where he came into contact with new attempts at approaching phenomenology through the works of Jean-Paul Sartre and Maurice Merleau-Ponty. Thus, if "Husserl employed phenomenological methods to analyse experience and human consciousness,... and Sartre analysed human freedom phenomenologically,... Merleau-Ponty advanced a phenomenological theory of bodiliness and human embodiment in the world." ${ }^{3}$ Suffice it to say, at a close lecture of Schillebeeckx's works, that these thinkers proved to be an unending source of inspiration for this Continental theologian. To resume, however, it is in this context of approaching phenomenology that the first chapter of Schillebeeckx's Jesus in Our Western Culture (here and after called JOWC) analyses creation as a realm which encapsulates the beginning of both salvation and perdition as two concepts present throughout Schillebeeckx's hermeneutic.

As human salvation is Schillebeeckx's greatest concern here, this account of creation infers that the history of salvation is to be searched for in the human history. Human history by itself is considered secular because it is anthropocentric and can be expressed in words known to men and women. Thus such concepts as well being, which we promote, or evil, which we fight against, help us envision a God who brings salvation for every man or woman through love. Love is the term that Schillebeeckx uses as an expression of the highest human ideal, i.e. human ethics. Love is meant to guide every human action in order to secure universal hope in the history of humanity. God disclosed his love in history both through the created order and through the life and ministry of Jesus Christ.

At this point, Schillebeeckx is ready to say that Jesus Christ is not the only one by whom God revealed himself within human history. There are also other religious factors which support the cause of humanity. Schillebeeckx takes this idea and transforms it into a postulate which makes him assume that terms like church and religion are not compatible, precisely because of the "liberating events" experienced by different religions. These liberating events, as Schillebeeckx calls them in his book, Jesus in Our Western Culture.

3 Kennedy, Schillebeeckx, 42. 
Mysticism, Ethics and Politics, ${ }^{4}$ are historical periods which make us conscientious of the present of God within history. This idea is also to be remembered because it makes Schillebeeckx's doctrine of revelation easier to understand.

Beside those liberating events which secure the continuity of God's revelation within human history, Schillebeeckx follows the traditional line of thought and asserts that the transforming death of Jesus of Nazareth was indeed the means to verify the truth of revelation. This observation is contradictory when it is compared with the concept of revelation in the writings of other representatives of this method of applying theology "from below". For instance, the statements issued by Wolfhart Pannenberg concerning God's self-revelation in Jesus Christ are related inextricably to Jesus' resurrection. Schillebeeckx associates God's revelation in Jesus to his ministry and death. For Pannenberg, the resurrection is precisely the only true historical event that anticipates the whole, unique and direct self-revelation of God in history. Jesus' resurrection was indeed proleptic because it realised in the present time all the eschatological expectations of both the people of the Old and the New Testament. On the one hand, the resurrection was a historical event as it meant the fulfillment of God's promises for the Jews of the Old Testament. On the other hand, it was the fulfillment of the pre-Easter claims made by Jesus that he was the self-revelation of God in history for the people of the New Covenant/Testament. There was no need for any apocalyptical expectations anymore, because Jesus' claim to be one with the Father has been verified and approved at his resurrection. And again, contrary to Schillebeeckx's claims, this is also an occasion for Pannenberg to bring into discussion the problem of Jesus' divinity as an emphasis on the reality of the Trinity:

In the framework of the revelational unity of God and Jesus, the divinity of Jesus has to be understood as the unity of the Son with the Father, which leads directly to the Christian understanding of God as Trinity. ${ }^{5}$

This assertion is set against both Schillebeeck's discussion on revelation as an interpretative series of historical events and his understanding of the relationship between revelation, God and humanity. The fact that Pannenberg sees the revelation of God in Jesus as direct (not at all

4 See Schillebeeckx, JOWC, 8, 10.

$5 \quad$ Ford, The Modern Theologians, 183. 
indirect or expected to become complete in the eschaton) due to the resurrection of Jesus implies two aspects. First of all, as Pannenberg has plainly shown, it receives a universal character and consequently it is open "to every one who has eyes to see". 6 Secondly, revelation already comprises the promises of God hoped for, those which were meant to be fully accomplished in the last days. However, this idea would raise a major question concerning the role of the Holy Spirit in the believer's life after the ascension of Christ and the importance of the doctrine of the second coming of Christ, a seemingly important teaching for Schillebeeckx because he addresses it from a Christological and also ethical perspective.

By giving way to the idea of suffering in his theology, Schillebeeckx attempts to explain the revelation seen through the eyes of the eschaton. This is precisely the opposite way Pannenberg understood revelation. Schillebeeckx's position is understandable only in relation to his concept of suffering which shapes the meaning of every revelatory event, and this realm lowers revelation to "the limits of history..., of language, and... of human vulnerability", making it a "revelation in the human dimension". As one may see throughout the compendium to his work, Schillebeeckx sketches an interesting and original image of the way in which human facts and words disclose the meaning of a certain historical action as being an event of liberation from suffering. In spite of one's expectation that a tradition of ethics should be the outcome of the divine word spoken to man, Schillebeeckx implies that

facts only become history within a framework of meaning, in a tradition of interpreted facts. This is the first level of meaning... Within a religious tradition of experience of belief in God, that human element of liberation is interpreted on a second level of meaning: in relation to God... The secular event becomes the material of the "word of God". In this sense, revelation has a sacramental structure. ${ }^{8}$

So far the dual nature of revelation as both an event happening within a certain tradition of interpretation (its first level, i.e. human) and as an episode in the life of divinity (its second level, i.e. sacred) appears to be the line within which Schillebeeckx defines this concept throughout his works. For him, revelation is therefore one of the "sacraments of nature", thus

Ford, The Modern Theologians, 182.

Schaeffer Rocha, "Neither Sola Scriptura, nor Solus Spiritus", 1173-1192.

Schillebeeckx, Jesus in Our Western Culture, 10. 
pertaining to humanity, whereby it receives "the religious significance that according to the historians of religions some phenomena and actions had in all cultures and religions". 9 Some difficulties could occur, however, as Schillebeeckx mentions a "tradition of experience", which suggests that the sacred which comprises the second level of interpreting the revelation is not necessarily recognizable throughout creation, meaning that although at some point the divine penetrated the secular realm in order to initiate a relationship, it is fair to say that yet another part of that secular realm remained outside this relationship.

\section{Revelation and religion}

Two problems emerge at this point. First of all, in the secularised realm, the term "revelation" could be misused because its first level of meaning is entirely anthropological. Secondly, there is a new element introduced by the second "level of meaning". At this level, Schillebeeckx assumes that the subject of revelation is the person of Jesus Christ. Consequently the object of revelation which allows a relationshionship to God or to what has been revealed becomes the community of believers, or simply the believer who grasps the real sense of revelation through the "word of God". It is particularly the otherness of God, which is an "underivable concrete phenomenon"10 that shapes the believer and helps him progress from the first level of interpreting this liberating event to the second level of understanding the event sacramentally. The non-believer is also able to interpret a certain event as revelation, but he can only do that on the basis of a language common to all people, that is, a language bound up with history. The non-believer cannot reach the theological meaning of revelation, but can establish a common language to debate the special event with the believer on the basis of his religious consciousness, and his human freedom "innately" and "analogically" deriving from "nature's radical otherness to God". 11

Schillebeeckx is very sympathetic and tries to explain very carefully the non-believer's place in a revelatory event. God first disclosed himself in nature, consequently the intended object of revelation was the believer as well as the non-believer. Schillebeeckx claims that God's presence in all these liberating events would finally unveil to the non-believer as it once

\footnotetext{
$9 \quad$ Borgman, Edward Schillebeeckx: A Theologian in His History, 209.

$10 \quad$ Schillebeeckx, The Collected Works of Edward Schillebeeckx, vol. X, 91.

11 Flynn and Murray, eds., Ressourcement. A Movement for Renewal in Twentieth-Century Catholic Theology, 367.
} 
did to the believer, and this is where Schillebeeckx sets on a different path than, say, Wittgenstein with his contrasting example of the happy man and the unhappy man when they both look at the world. ${ }^{12}$ To Schillebeeckx, the non-believer is not so different from the believer in this event, because they both have the conscience of a greater instance than human history, which secured the event as liberating. However, both the believer and the non-believer are unable to escape the reality of human mediation in a revelatory event. If Jesus of Nazareth, for example, was just an extraordinary man, one may ask if the revelation is really about God's word spoken to man or is it rather man words spoken to man. This is, after all, a valid question in the context of movements such as Death of God theology, which embraces the thought that recent events in Western culture altered "the conditions of human experiences; man has learned to understand the world and to order his life apart from God. God is dead in the way Latin is dead."13

Nevertheless, Schillebeeckx makes his point clearer on this subject by stating that religion provides humans with the consciousness of God, and thus it represents a distinct segment within the history of humanity. All of a sudden, secularism encounters Christianity due to Jesus' death, which transforms the history of human suffering into the reality of eternal life. Moreover, this is the point where human history meets the history of revelation. Therefore, religion is "the place where men and women become explicitly aware of God's saving actions in our world-wide history and in which this saving actions within history call religions and religious salvation to life."14

For Schillebeeckx this assertion is not a means of analysing which religion came out of which or, for that matter, which one is more important; instead, it is for him an occasion of saying that different religions are the scenes of interpretative experiences of salvation from God. Religions in their diversity are the scene of God's revelation, especially in the context of suffering, which is profoundly human. They are universal, thus revelation itself has a universal character. Schillebeeckx continues this idea by saying that any tentative notion of bringing together the experience of salvation with concepts like religion and church as synonymous is "exclusivist". In other words, Schillebeeckx sets the basis of a more articulate dialogue between a theologian and a historian of religions, who would otherwise find it difficult to

12 Wittgenstein, in Rego, Suffering and Salvation, 190.

13 Rose, "Death of God Fifty Years On", 43-48.

14 Schillebeeckx, Jesus in Our Western Culture, 8. 
approach religious matters from the partial point of view of the phenomenology of philosophy. Schillebeeckx the theologian, who in this instance speaks for the phenomenology of religion ${ }^{15}$, considers that salvation has a more profound origin than an intellectual or philosophical opinion. We need to search for this origin in the history of humanity, which for him "is not entirely the same thing as the history of revelation". ${ }^{16}$ Without universal salvation, Schillebeeckx says, a special revelation like that reflected in the life and death of Jesus of Nazareth is meaningless.

\section{Historical/“liberational” dimensions of revelation and phenomenology}

While explaining the process of interpreting the revelation, Schillebeeckx retains several Bible passages beginning with Exodus in the Old Testament up to the history of Jesus interpreted by his apostles as the Messiah. Schillebeeckx asserts that after Moses killed the Egyptian, his brothers from several Semitic tribes stood up at his side against Pharaoh and released themselves from its tyrannical oppression. This moment remained in the secular history and conscience as a "liberating event". Only after several centuries, at the time YHWH believers initiated the tradition of re-reading major historical events, this particular reference became known as a "saving event". What Schillebeeckx means is that the YHWH believers were keen on transforming the old historical memories into explicit themes of the Old Testament. That is, they succeeded in drawing a clear distinction between a particular and antique movement in the history of humanity and the salvation history of the Hebrew tradition. This is an excellent example of how Schillebeeckx understands the transition from the mere interpretative experience to the "language of faith" which acquired material form with the raise of faith in God:

[Believers in God] arrived at the experiential insight that the Lord has saved his people from Egypt. Here the structure of salvation history and the history of revelation becomes clear...

15 For the need to put these traits together in a more qualitative debate on mystery and reason, see Dupré, Religious Mystery and Rational Reflection, 98-101.

16 Schillebeeckx, JOWC, 9. 
Human talk about the transcendence of God has no other ground than our contingency... as a possible "deciphering" of deeper dimensions which can nevertheless be experienced. ${ }^{17}$

This is to say that a revelatory event can be conceived only on the grounds of human language which supports every religious tradition if religious tradition is understood as the totality of models which work as mentors in the believer's life. Thus, Schillebeeckx tackles the nature of revelation and salvation, whereby the said contingency becomes the "experience of consciousness" that would consequently make revelation relevant to modern phenomenology. ${ }^{18}$

Almost the same thing happened with the life of Jesus of Nazareth. He is to be understood as a man in his own historical environment, but with a special task: that of liberating men and women, which is the most noble ethical action. Nevertheless, his historicity only provides us with Jesus' liberating mission. The salvation that his life evokes was experienced by his followers only after the consummation of his death. He was then to be recognised as Jesus the Messiah, as a special Son of God. Schillebeeckx adds another commentary to this by saying that "without Jesus' historical human career, the whole of Christology becomes an ideological superstructure." ${ }^{19}$ It is important to notice, however, that the divine attributes of the Saviour are not the material of his human nature, that is, they were not brought into existence at Jesus' natural birth: they are eternal. His divine nature is not a question of deduction but, as Schillebeeckx very well noticed in other instances, it is a problem of confession. If the confessional aspect is not being stressed, one cannot assert, as Schillebeeckx does, that the religious meaning of Jesus' earthly life suddenly becomes a revelatory one. This means that the proclamation of Jesus' double nature is not at the hand of secular criticism, but is an act of faith. Nevertheless, it is debatable if such confession today would have the same meaning as for Jesus' disciples, for whom recognizing Jesus as God had much to do with his nominal question and their personal acknowledgement. ${ }^{20}$ Schillebeeckx challenges us with a delicate question: whatever religious meaning Jesus' human life could involve, it was not complete outside the revelation of his divinity, which is confessional:

\footnotetext{
$17 \quad$ Ibid., 12.

18 Steinfels, "Edward Schillebeeckx, Catholic Theologian, Dies at 95", A.26.

19 Schillebeeckx, JOWC, 13.

$20 \quad$ See Tilley, The Disciples' Jesus, esp. chapter 2, note 3).
} 
...unless we also take into account the positive relationship of Jesus to God, above all his Abba experience, this human liberating event that Jesus is never leads to a liberating Christology and soteriology. In that case there is a break between Christology and ethics, between Christ mysticism and ethical commitment, both personal and political. ${ }^{21}$

Here a problem arises: if those who confess Jesus as Christ, as Messiah, are the believers only, what happens to the alternative? In other words, what is the role of human consciousness in a process where the liberating historical event becomes a saving and soteriological action?

Schillebeeckx answers that what revelation accomplishes in human beings is not the creation of a superior being endowed with higher degrees of consciousness than other humans. Revelation only opens humanity to the religious meaning of well motivated human action carried for the best of society and politics in the "secular" world. In this context, the reason we have the Scriptures is that they provide us with the right way of understanding God's action in our human history. They present us to what Schillebeeckx calls the "divine way" in all the liberating movements in history. On the other hand, they also teach us that the "human way" or the religious conscience by which people act is not entirely God's way, because God is not restrained by our limited life and history:

[God] does not coincide with any particular historical liberating event, not even with the liberating exodus event of the Jewish people... The name of God, for Christians symbolised in the name Jesus Christ, can be misused not only by oppressors but also by liberators...; he is a liberating God - liberating constantly by means of men and women, but at least in the end never in a purely human way. ${ }^{22}$

From a simple comparison with the theology of liberation, the concept of God that Schillebeeckx is promoting is greater than the concept of God promoted by liberals. In trying to define God to modern men and women, Schillebeeckx associates him to the concept of suffering which is familiar to us and can be removed precisely because God is said to have all the attributes needed to change suffering into happiness. Notice, though, that Schillebeeckx is not a political theologian seeking to introduce us to the concept of suffering as present in

$21 \quad$ Schillebeeckx, JOWC, 13.

Ibid., 14. 
Jürgen Moltmann and Johann Baptist Metz. Like Metz, however, he is concerned with men and women for whom the social and political life represent a real challenge in everyday existence. $^{23}$ The difference between them, however, is that Schillebeeckx does not link the concept of suffering to a political situation, but defines anthropology in relation to the inner self of the individual. However, this makes the object of our future interest in Schillebeeckx's thought.

Schillebeeckx insists that revelation is not to be confounded with human suffering or human history. This is precisely because God is the totally other and also because human suffering changed its meaning in time. ${ }^{24}$ Today there is a different kind of anthropology than the one which made the object of the Middle Ages, at least from an ecclesiological point of view. Nowadays men and women do not expect for salvation to be brought to them on the basis of a pre-understood (à-priori) notion of God. From a phenomenological point of view, nowadays men and women want to make salvation urgent and they express the need for a redefined, "re-understood" divinity. It is a reality that makes Schillebeeckx draw a sharp comparison between the Middle Ages "churchly times" and modern "religious times":

God, the hope of religious man, had in the past to function as his refuge in those secular spheres in which he had not yet achieved a firm hold on the world and human society... Now that man seems to be capable of coping with the world on his own, he no longer appeals to God and the Church to supply for its impotence. This aspect of the modern phenomenon can legitimately be called secularization. ${ }^{25}$

In modern times God is not sought as a mere "supplement" for the helplessness of human social life. Modern times are religious not because churches are built up all over the earth but because social suffering seeks its healing in meaningful liberating events. The suggestion Schillebeeckx is making regarding modern man seems to imply that secularization, man on himself, is no better solution for the future of humanity that has suffering as destination. In this

23 See Boeve, Depoortere, and van Erp, eds., Edward Schillebeeckx and Contemporary Theology, 70 fwd. 24 Schillebeeckx, The Collected Works of Edward Schillebeeckx, vol. X, 178; Poulsom, The Dialectics of Creation, note 273.

25 Schillebeeckx, God the Future of Man, 173-174. 
context, and somehow in relation to Moltmann's position on suffering history ${ }^{26}$, Schillebeeckx claims that the concept of God is to be defined in terms related to these men and women's actual historical condition, but must not be identified with the experience of suffering. As dramatic as human suffering may be, Schillebeeckx also advises that we should not minimise God, who is still the "totally other" in every instance. Schillebeeckx is very sympathetic to the theology of liberation up to a certain point, that of retaining the attributes of God as alterus. We have to understand that there is still a break between mysticism and politics, between communion with God and political action for humanity. This was meant by Schillebeeckx when he said that the human way followed from the divine way in history.

In the beginning of the second chapter of $J O W C$, Schillebeeckx takes us back to the original designation of the name "Jesus Christ". He states that, without being a proper name, but a double name with a confessional character, this name evokes both a historical reality and an eschatological promise. Jesus Christ thus is on the one hand a historical messenger with a special message from God, and on the other hand the Messiah promised in the Old Testament to the next generation of Israel: in the context of Israel both characteristics involve some anthropological peculiarities whose historical data are conclusive for the phenomenology of religion. ${ }^{27}$ Living in Nazareth, Jesus has strong historical roots which need not be overlooked, otherwise confession about Jesus Christ is irrelevant. Moreover, without the confessional character of the name Jesus Christ, which "provides the basic structure of all Christology"28, the name Jesus of Nazareth presents no importance today. All New Testament's records about Jesus Christ, Schillebeeckx reckons, lead to the impressive and outstanding career of Jesus of Nazareth:

In modern times this reference to history is at the same time an expression of Christian opposition to ideological misuse of the name of Jesus Christ, for the church's use of the name Christ is subject to the criticism of the name Jesus, to the criticism of his message, and the distinctive nature of his career, which led to his death. ${ }^{29}$

\footnotetext{
$26 \quad$ See Moltmann, The Crucified God, 2015.

27 See a portrait of the Messiah in context, in Leaf, The Anthropologies of Western Religions, 123.

28 Schillebeeckx, JOWC,15.

29 Ibid., 15.
} 
Nowadays, Schillebeeckx's concern for the historicity of Jesus Christ is understandable. The purpose of making Jesus more historical is to demythologise Christology, to set it on a material and objective foundation in time. But what is, on these grounds, the relationship between Christ and God? Is the Trinity a simple ideological approach which in itself does not exist except if it is put into words acceptable for today's men and women? If Christianity removes the ideological displacement of the name Jesus Christ by demythologization, what happens to the Doctrine of God and the Holy Spirit? One has to keep in mind that God is not a mythical being, but an entity which is active in history through his word and deeds.

Throughout his entire work, Schillebeeckx always takes time to describe the God of Jesus and their relationship to each other. Like the rest of us, Jesus can be best defined in terms related to his spirituality (his relationship to God) and his character (his relationship to humans). Schillebeeckx establishes two coordinates which help us get a better description of how God is and how he is active in our history. Firstly, Jesus' entire life was a portrait of God, and secondly, the way we can get to know God is in the light of the reciprocal relationship between Jesus of Nazareth and God, which forms Schillebeeckx's theory of the "Abba experience" 30 . In developing his "Abba theory", Schillebeeckx points out that, even if Jesus was the "decisive and definitive revelation" of God, he always had the conscience that "the Father was greater than him", as John 14:28 shows. This is one of the Bible verses on which Schillebeeckx consolidates his "Abba" theory as a process of development in Jesus' cognition that he was the son of God. There is no doubt that Schillebeeckx works primarily with the biblical text in trying to offer his readers a better orientation throughout the major Christian doctrines. In hermeneutics his efforts to reorientate the reader towards the very essence of the Christian faith is quite praised; however, his supporters often find themselves reproving Schillebeeckx for being too daring with the "Abba" theory or subjects related to it, like Christology and aspects of the resurrection. ${ }^{31}$ It could be said that Schillebeeckx's account on Jesus as the Son is incomplete and at times misleading, because it either corrects or adds to accounts about him already given in both the Old and New Testament. For instance, when Jesus is said to have spoken of the kingdom of God as the symbol of salvation for humanity, Schillebeeckx counts it as an occasion for Jesus to submit himself to God and his purposes

$30 \quad$ Ibid., 17.

$31 \quad$ See Schreiter quoted in Ford, The Modern Theologians, 159. 
primarily as part of the created order and secondly as the Christ coming to judge the nonrepenting nature:

Jesus is involved in the eschaton of creation, so precisely because of that Colossians in particular also gives Christ a role at the beginning of creation, just as wisdom dwelt with God... when he created the world... The early-Jewish missionary confession of faith continues to exercise its influence, in a Christian interpretation... Here (in 1 Thessalonians 1:8) faith is faith in God and Christology is an ingredient of faith in God. There is as yet still no mention of faith in Jesus Christ; this is the object of eschatological hope. ${ }^{32}$

The eschatological hope coming from faith in the second coming of Jesus as the Christ is part of a "tripartite creed". This tripartite creed is represented by: (a) the faith in God as the Creator; (b) the belief that there will be a judgement day for the unrepentant; (c) the eschatological hope for those who repent.

\section{Church and world. Towards Schillebeeckx's hermeneutic methodology}

With the third chapter of the book JOWC, we move towards a more precise definition of the concepts of ministry, anthropology, and social ethics in the theology of Edward Schillebeeckx. This third chapter opens the second-half of his book. If the first-half was mainly orientated towards the relationship between the God of the Old Testament and the cosmic ethics articulated in the experience of creation and salvation through Jesus of Nazareth, the chapter about the church-world relationship opens somehow strategically the second-half of the book. It is already a statement in Schillebeeckx's theology from his early works to the latest to link "the specifically ecclesiological and sacramental with an underlying fundamental theology of revelation and salvation" 33 , and so far we have analysed these traits and their specificity. From the very beginning, Schillebeeckx introduces us to a new area of interest, namely the doctrine of the church and its "human face", the world. Consequently, what Schillebeeckx does is to suggest both the way of interpreting the outcome of Jesus' sacrificial death on the cross, that is, the birth of the church, and the reason for the existence of the church, that is, the mediation of the divine disclosure into our human history. Thus, given the inner structure of the book and

32 Schillebeeckx, Christ - the Christian Experience in the Modern World, 525.

33 Thompson, "The Church as Sacrament", 33. 
Schillebeeckx's thinking, the church is called to proclaim the transitional character of ethics from a cosmological to an anthropological dimension, in an effort which in his book from 1985, The Church with a Human Face, was coined as a "new and expanded theology of ministry". That is, the church is the place in which the act of salvation in Christ becomes a genuine historical event for nowadays men and women. As a Catholic, Schillebeeckx is eager to underline that the church makes the transition from doctrine to history, from the things belonging to the cosmic order to the things belonging to contingency.

Nevertheless, contrary to the directives of the Catholic Church, Schillebeeckx does not give much credit to the church as an institutional defensor fidei (a self-proclaimed attribute of the Catholic Church otherwise known in the Netherlands as pietas ordinum). ${ }^{34}$ Rather, Schillebeeckx tries to develop a new way of talking about the church with an accent on the social and natural character of Christian dogma. The reason why he finds it uneasy to present a traditional image of the church is that, as he says, hundreds of years of church life have taken the doctrine away from people and thus broken the balance between theology and humanity: 'We need a bit of "negative ecclesiology", church theology in the minor key, to achieve a healthy balance, in order to undo the centuries long ecclesiocentrism of the empirical phenomenon of "Christian faith... for God's sake, for the sake of Jesus the Christ and for the sake of humanity". ${ }^{35}$ Schillebeeckx's concern is not the reiteration of the doctrinal status of the church. Instead, he reiterates the famous quote of the nouvelle théologie that theology must start from below. The hint that it should "begin from humanity and raise toward God" was also present in Barthian theology, but what this new theological wave did was to elaborate on the concept. ${ }^{36}$ Schillebeeckx maintains that faith must be defined in human language, so that the Christian phenomenon might regain its empirical dimension and become a religion of the people as it once was. As a consequence of this idea, Schillebeeckx urges that the redefinition of the church infers as a precondition the redefinition of the main Christian doctrines to which we payed attention in the first chapter of $J O W C$.

Hence, Schillebeeckx speaks of the church from a twofold perspective. In the first place, he speaks of the doctrinal or theological dimension of the church. The first chapter of $J O W C$ left us with an open question regarding the role of the church within God's eternal plan

$34 \quad$ Kuyper, On the Church, esp. chapter 27, note 53.

35 Schillebeeckx, JOWC, 31.

36 See details in De Bary, Theological Reflection, 23. 
of transforming the "secular history" into "salvation history". The question, as Schillebeeckx put it, refers to the role of the church in this process, whether it mediates the significant transformation or not. To clarify, though, this dimension of the church would imply the clarification of Christian doctrine, and it is more philosophical in nature. It envisages rather the rethinking of the concept of God, Jesus and creation, without giving an explicit statement about the role of the church as mediator, because "[our] direct contact with the highest reality" is presupposed without the authority/mediation of the church. ${ }^{37}$ Only in the second place does Schillebeeckx speak of the church as having a relational dimension. Only when it comes to "the relationship of the church of Christ to Jesus of Nazareth", is the role of the church in the salvation history clarified as it retains both the significance of the sacraments for the believers and the core of Christ's presence in the community in a so-called "social phenomenology of ecclesial presence". ${ }^{38}$ As Schillebeeckx stated in the first chapter of JOWC, if the death of Jesus was necessary in order to redo the unity between God and humanity, his resurrection would set Jesus of Nazareth in a new light as the Christ of faith by the mediation of the community of faith which is the church:

One can say that the "church of Christ" which came into being on the basis of the resurrection of Jesus is the deepest significance of the "appearances of Jesus": in the church community "assembled" in faith there appears, is present, the crucified but risen Christ. ${ }^{39}$

Thus, the church of Christ already receives a relational significance secured only by the resurrection of Jesus. The church was the one to interpret the 'appearances of Jesus' as resurrection and in this power was enabled to mediate the message of Jesus' death to the world as salvation from suffering. In this sense, the second perspective from which Schillebeeckx defines the church as having a relational and also an ethical structure. This implies the mediation of the benefits of Jesus" death to the "dehumanised" 40 and its purpose is to bring

37 See the early Mediaeval roots of this idea defined in Kersten and Zaner, eds., Phenomenology: Continuation and Criticism, 47.

38 McKenna, "Eucharistic Presence: an Invitation to Dialogue", 291-317.

39 Schillebeeckx, JOWC, 27-28.

$40 \quad$ Ibid., 27. 
about the Kingdom of God or the humanum, the full realization of humanity according to God's eternal plan for it.

In the closing part of his discussion on the church, Schillebeeckx approaches a more recent theme in theological talk about this institution, namely the communion of the Church with other Christian churches, which he calls the "pluralism of the Christian churches". Schillebeeckx is keen on understanding the concept of pluralism in this context as unity between all the churches of Christendom, in line with the new political orientation of the Roman Catholic Church since the $2^{\text {nd }}$ Vatican Council.

Given the two perspectives from which Schillebeeckx defines the church, i.e. the doctrinal and ethical perspectives, future discussions will follow the logical path already familiar to us from the first chapter. Hence, the subject on the relationship between church and world will take the place of the previous debate regarding the relationship between God and creation, whereas the subject on the relationship between church and Jesus of Nazareth will replace the previous Jesus-world debate. This circular orientation of the book gives Schillebeeckx the opportunity to reiterate the importance of Christian dogma and faith in the light of a new and redefined reality for contemporary men and women, and also to draw near to the final part of his book, the importance of Jesus as ethics for nowadays society and politics.

As stated before, Schillebeeckx's soteriology in JOWC proves to be more historical, in a chronological way, than dogmatical. What is meant by this is that Schillebeeckx always reminds us that at first the idea of salvation did not have a religious character but was bounded historically. ${ }^{41}$ It was a "worldly reality" due to the fact that it was born in the very context of creation without any religious influences whatsoever. In fact, in the first part of the book, Schillebeeckx gives so much credit to creation that he attributes to the natural order a sacramental meaning. Creation is indeed the sacrament of God in history because it encapsulates all the particularities of the future Kingdom of God, given both the characteristics of human persons and the purity of the natural environment. As Schillebeeckx put it,

Creation is a blank cheque to which only God himself stands guarantor. It is a vote of confidence which gives the person who believes in the creator God

$41 \quad$ Problem discussed by Yarbrough, The Salvation Historical Fallacy?, 122. 
the power to believe... that the kingdom of God... is in fact in the making for humanity, in the power of God's creation. ${ }^{42}$

Therefore, creation in itself was, in the Old Testament, the unveiling of God's love and salvation and it was perceived as such in the consciousness of ancient men and women. Likewise, Schillebeeckx continues his thoughts in the third chapter by saying that, in the new order to which we are exposed in the New Testament, the church is perceived as a "sacrament" or a sign of God's salvation in this new historical context. Most interesting here is the fact that one may need to differentiate between the church in itself as the unveiling of God and the church in the world or the outward church. The reason is that in the first chapter Schillebeeckx presented a specific situation where the revelation of God in creation meets the religious need of the human person, and thus revelation comes to be understood as liberation from historical suffering. In this circumstance, Schillebeeckx sought to explain revelation to the believer as particular and higher than the revelation to the non-believer or to the religious man because they do not interpret the meaning of revelation in the same way. ${ }^{43}$ Nevertheless, Schillebeeckx is very careful not to misuse the meaning of salvation when he clarifies the sense of revelation. This is to say, although particular religions and different churches are the expression of man's need for salvation, they are not in themselves salvation, because salvation entails a much higher meaning and a special human mediation in the person of Jesus from Nazareth. Although Schillebeeckx does not make very clear yet what is the role of the "church of Christ" and whether it can be identified with the church witnessing a post-Easter Jesus, it is less clear whether Schillebeeckx makes any difference at all between religion and church as soteriological sacraments. This question comes on the basis of Schillebeeckx's statement that

[Religions and churches] are the explicit identification and ultimate fulfillment of... salvation. Churches are the places where salvation from God is made a theme or put into words, confessed explicitly, proclaimed prophetically and celebrated liturgically. So there is an unbreakable relation between "world" and "religion". 44

$42 \quad$ Schillebeeckx, JOWC, 18.

43 An idea opposed by Rosenzweig quoted in Rashkover, Revelation and Theopolitics, 79.

$44 \quad$ Schillebeeckx, JOWC, 32. 
The question above stays if we think of the implications of Schillebeeckx's statement on his concept of church ecumene. This statement identifies the ecumenical character of the church and the very concept of ecumene with the unity of the Christian churches, rather than with other significant world religions like Hinduism, Buddhism or Islam. It also shows that the church interpretative frame of the Jesus event can provide the hermeneutical basis for "a contextualised response to the [divine] discourse" related both to incarnation and salvation ${ }^{45}$. To resume Merleau-Ponty's idea that phenomenology is related to the "human embodiment in the world" ${ }^{\prime 4}$, in the first chapter of JOWC Schillebeeckx himself argued that the soteriological experiences of the believer are to be set above the liberation experiences of the non-believer (called the religious experience). How, then, is Schillebeeckx right to maintain that both religions and churches are the anamnesis of God's saving presence in the world? In this context, the ecclesiastical sacraments find their basis in the events before and after Easter, so much so that the existence of the church is not sustained exclusively by social and political activity. This Christian conviction is a biblical statement and it represents the very RomanCatholic teaching regarding the birth and the future of the church (Matthew 16:17-19). Contrary to this, Schillebeeckx asserts that religions and churches must prove effective social implication, on one condition, however: that of not perverting their functions which can be sacramental or ritualistic:

... churches have a wrong understanding of themselves: (a) if they do not understand themselves in relation to the world events; and (b) if in their participatory and interpretative relationship to world events they think that they can abandon specifically religious forms like confession, word and sacrament. If the churches have a political significance, this significance must find its basis in the mystical dimension of the church and not in secular power. $^{47}$

45 Meadowcroft, "Between Authorial Intent and Indeterminacy”, 199-218.

$46 \quad$ See Kennedy, Schillebeeckx, 42.

47 Schillebeeckx, JOWC, 33. 
This last statement shows that Schillebeeckx should not be confounded with a religious partisan. However, one may still want to wait for explanations regarding the meaning of genuine mysticism and politics, which Schillebeecks only offers at the end of his book. Nevertheless, the impression that is being created here is that one needs to divide the concept of religion and church into two separate and very distinct aspects of human faith. This is because Schillebeeckx identifies the so-called universal conscience of creation about God and salvation (as in the first chapter of $J O W C$ ) with a "universal saving presence" which the concept of religion entails while it ignores the latter's more particular characteristics. ${ }^{48}$ What is meant here is that in this context the conscience of creation is one with the religious conscience of the modern man. Thus, the concept of church is not at stake here anymore than the concept of religion, although one individual does not share the same religious conviction with another individual and even if the fundamental doctrines of world religions do not share a common content and practice.

Indeed, Schillebeeckx speaks indeed of world religions individually, but the concept of church is not identified as a unique ecclesiastical instance. Moreover, the Christian church is not at all "the one [and only] church", a particular concept as in Hans Küng's The Church from 1976, but it is rather a "segment of faith" among many other "segments of our human history". Consequently, "synagogues and pagodas, mosques and churches" are religious forms and religions, as "Hinduism, Buddhism, Israel, Jesus, Islam... are a segment of our human history and cannot be understood without this "profane history", 49

What is more interesting is that in his Western context Schillebeeckx switches easily between the functions of the church and the particularities of religions. The fundamental functions of the church are well known by Schillebeeckx, who identifies them as: confession, word (or the function of proclamation) and sacrament (his writings on the Eucharist, ordination and marriage, for instance, have had a sound influence both on clergy and laymen in the Roman Catholic Church):

Confession and word, sacrament and practice of faith, action to heal and to open up communication... do not make the experience of the world event

48 A phrase similar to the "universal consciousness of creation" employed and defined by Richard Niebuhr quoted in Sherman, The Shift to Modernity, 226.

Schillebeeckx, JOWC, 33. 
superfluous, while the so-called worldly "outside event" makes speaking in the language of faith and Christian praxis necessary... Historical and also social and political praxis in the world cannot be separated from action in proclamation, pastorate and sacraments. To break this connection is to damage the inner structure of religion and church. ${ }^{50}$

With Schillebeeckx, however, these ecclesiastical functions receive a broader meaning as "specifically religious forms". This is precisely the reason why we mentioned the need to divide Schillebeeckx's interrelated concepts of religion and church into two separate concepts. We also have to keep in mind Schillebeeckx's comparison between the church as the unveiling of God and the world as the veiling of God, especially if religion is understood as a "segment of profane history". ${ }^{51}$ In this context, to identify religion with the church is to erase the imminent line of demarcation between the "sacrament" of the Christian faith (a title for church in Schillebeeckx) and the "outside event" of human experience of God present in world religions.

\section{Conclusions}

Schillebeeckx's thought on the relationship between God and human history was an opportunity for us to analyse the means of God's disclosure within humanity or God's revelation. This long trip started in the Old Testament, where God used the created order as a means to reveal his being. Schillebeeckx thinks that the awareness of God's revelation in creation is common to all people, thus it is not a prerogative of one nation only.

The universality of God's revelation suggests the fact that revelation implies two different meanings. There is a first level of understanding revelation, which is merely anthropological. It does not assume faith in God, but rather a common language about God. Therefore, this first level is called "the level of experience" and his subject is the non-believer. The second level of understanding God's revelation was named here "the level of meaning", and this study envisaged the category represented by this level, namely the believer. The believers are thus able to define God properly through the "word of God" disclosed in the historical person of Jesus Christ.

$50 \quad$ Ibid., 34.

Ibid., 33. 
Later on, the salvation ministry of Jesus was follow through this tradition of meaning, in which the community of believers ascribed to Jesus the supernatural qualities which the title of Messiah evoked only after his sacrificial death. Thus the role of Jesus as the Saviour, the Messiah, is thought to have a confessional character in this hermeneutic tradition.

The nature of the divine disclosure within human history was analysed here in the context of the church from a twofold perspective, beginning with Schillebeeckx's attempt at defining his phenomenological method in relation to the doctrinal or theological dimension of the church in God's eternal plan to transform secular history into salvation history. In this process, Schillebeeckx reckons, the role of the church is either to mediate the disclosure or to transform human history by reconceptualizing the Christian doctrine. The other means Schillebeeckx employs toward a particular phenomenology is to recontextualize the church in its relational dimension, and thus clarify the role of the church in the history of salvation.

While in Old Testament times, creation was perceived as the unveiling of God's love and salvation within history, thus being kept alive in the consciousness of ancient men and women, Schillebeeckx points out that in the new order, where we are introduced by the New Testament, the church in his definition is the new "sacrament" or sign of God's salvation for today's men and women.

\section{Acknowledgement}

This paper is part of a two-year postdoctoral research program (2015-2017) at the Faculty of Theology, the Department of Practical Theology within the University of Pretoria, South Africa, under the supervision of Professor Johann Meylahn.

\section{Bibliography}

Abdul-Masih, Marguerite. Edward Schillebeeckx and Hans Frei. A Conversation on Method and Christology. Toronto: Canadian Corporation for Studies in Religion, 2001.

Boeve, Lieven, Frederiek Depoortere, and Stephan van Erp, eds. Edward Schillebeeckx and Contemporary Theology. London and New York: T\&T Clark, 2010.

Borgman, Erik. Edward Schillebeeckx: A Theologian in His History, volume 1. Translated by John Bowden. London and New York: Continuum, 2004. 
De Bary, Edward O. Theological Reflection. The Creation of Spiritual Power in the Information Age. Collegeville, MN: The Liturgical Press, 2003.

Dupré, Louis K. Religious Mystery and Rational Reflection: Excursions in the Phenomenology and Philosophy of Religion. Grand Rapids, MI: Eerdmans, 1998.

Flynn, Gabriel, and Paul D. Murray, eds. Ressourcement. A Movement for Renewal in Twentieth-Century Catholic Theology. Oxford: Oxford University Press, 2012.

Ford, David F. The Modern Theologians. An Introduction to Christian Theology in the Twentieth Century. Second Edition. Oxford: Blackwell, 1997.

Kee-Fook Chia, Edmund. Edward Schillebeeckx and Interreligious Dialogue. Perspectives from Asian Theology. Eugene, OR: Wipf and Stock, 2012.

Kenedy, Philip. Schillebeeckx. Collegeville, MN: The Liturgical Press, 1993.

Kersten, Fred, and Richard M. Zaner, eds. Phenomenology: Continuation and Criticism. The Hague: Martinus Nijhoff, 1973.

Küng, Hans. The Church. New York, NY: Sheed and Ward, 1976.

Kuyper, Abraham. On the Church. Collected Works in Public Theology. Bellingham, WA: Lexham Press, 2016.

Leaf, Murray J. The Anthropologies of Western Religions. Ideas. Organizations, and Constituencies. New York and London: Lexington Books, 2014.

McKenna, John H. "Eucharistic Presence: an Invitation to Dialogue." Theological Studies 60.2 (1999): 294-317.

Meadowcroft, Tim J. "Between Authorial Intent and Indeterminacy: the Incarnation as an Invitation to Human-Divine Discourse.” Scottish Journal of Theology 58.2 (2005): 199218.

Moltmann, Jürgen. The Crucified God. Norwich: Hymns Ancient and Modern, 2015.

Poulsom, Martin G. The Dialectics of Creation. Creation and the Creator in Edward Schillebeeckx and David Burrell. London and New York: Bloomsbury T\&T Clark, 2014.

Rashkover, Randi. Revelation and Theopolitics. Barth, Rosenzweig and the Politics of Praise. London and New York: Continuum T\&T Clark, 2005.

Rego, Aloysius. Suffering and Salvation. The Salvific Meaning of Suffering in the Later Theology of Edward Schillebeeckx. Louvain: Peeters/Eerdmans, 2006. 
Rose, Matthew. "Death of God Fifty Years On.” First Things: a Monthly Journal of Religion and Public Life 265 (2016): 43-48.

Schaeffer Rocha, Abdruschin. "Neither Sola Scriptura, nor Solus Spiritus: The Revelation in the Human Dimension." Horizonte 14.44 (2016): 1173-1192.

Schillebeeckx, Edward. World and Church. New York, NY: Sheed and Ward, 1971.

Schillebeeckx, Edward. The Church with a Human Face. A New and Expanded Theology of Ministry. New York, NY: Crossroads, 1985.

Schillebeeckx, Edward. Jesus in Our Western Culture. Mysticism, Ethics and Politics. London: SCM Press, 1987.

Schillebeeckx, Edward. Christ - the Christian Experience in the Modern World. London: SCM Press, 1990.

Schillebeeckx, Edward. The Collected Works of Edward Schillebeeckx, volume X: Church. The Human Story of God. London and New York: Bloomsbury T\&T Clark, 2014.

Schillebeeckx, Edward. God the Future of Man. New York, NY: Sheed and Ward, 1968.

Sherman, Robert J. The Shift to Modernity. Christ and the Doctrines of Creation in the Theologies of Schleiermacher and Barth. New York, London: T\&T Clark, 2005.

Steinfels, Peter. "Edward Schillebeeckx, Catholic Theologian, Dies at 95." New York Times (Jan 17, 2010): A.26.

Thompson, Daniel Speed. "The Church as Sacrament: Schillebeeckx's Contributions to the Construction of a Critical Ecclesiology." Religious Studies and Theology 17.1 (1998): 33.

Tilley, Terrence W. The Disciples' Jesus: Christology as Reconciling Practice. Maryknoll, NY: Orbis Books, 2008.

Yarbrough, Robert W. The Salvation Historical Fallacy?: Reassessing the History of New Testament Theology. Dorset: Deo Publishing, 2004. 